\title{
MANAGEMENT OF PRODUCTIVE WAQF IN ISLAMIC BOARDING SCHOOL FOUNDATION ADLANYAH TAMPUS UJUNG GADING LEMBAH MELINTANG DISTRICT
}

\author{
Doli Witro, Ike Yulisa, Ali Hamzah, \\ Institut Agama Islam Negeri (IAIN) Kerinci, \\ J1. Pelita IV, Sungai Penuh, Sumur Gedang, Kerinci, Jambi, 37112 \\ Email : doliwitro01@gmail.com, ikeyulisa5@gmail.com, alihamzah311268@gmail.com,
}

\begin{abstract}
Abstrak
Pengelolaan wakaf harus diarahkan kepada pengelolaan wakaf secara efektif dan efisien. Pengelolaan wakaf merupakan proses membuat perencanaan, pengorganisasian, kepemimpinan, dan pengawasan berbagai usaha dari nazhir, kemudian menggunakan semua sumber daya organisasi untuk mencapai sasaran. Menurut data yang didapatkan Yayasan Pondok Pesantren Adlaniyah mempunyai kekayaan berupa tanah, tanah itu berasal dari wakaf Nazri Adlani dan dibeli dari warga. Di atas tanah tersebut telah berdiri bangunan berupa kelas dan asrama sebagian lagi ditanami sawit. Hasil dari kebun sawit pada awalnya dipergunakan untuk operasional sekolah tetapi beberapa tahun terakhir hasil kebun sawit diambil oleh pihak yayasan. Sementara menurut ketentuannya wakaf seharusnya untuk kepentingan umat akan tetapi kenyataannya digunakan untuk kepentingan pribadi. Berangkat dari hal ini penulis ini melakukan penelitian lebih lanjut mengenai pengelolaan wakaf produktif di Yayasan Pondok Pesantren Adlaniyah Tampus Ujung Gading Kecamatan Lembah Melintang Dalam penelitian ini, penulis menggunakan jenis penelitian lapangan (field research) yaitu melakukan penelitian lapangan dengan melakukan wawancara langsung kepada pengurus Yayasan Pondok Pesantren Adlaniyah mengenai pengelolaan wakaf produktif di Yayasan Pondok Pesantren Adlaniyah Tampus Ujung Gading Kecamatan Lembah Melintang guna mencari data secara lengkap yang berkaitan dengan permasalahan ini. Dalam penelitian ini, penulis mencari dan mengumpulkan data-data melalui wawancara dan dokumentasi di Pengurus Yayasan dan Pondok Pesantren Adlaniyah. Untuk memperoleh data yang relevan penulis menggunakan teknik pengumpulan data, wawancara, observasi, dan dokumentasi. Setelah data diperoleh, akan dianalisa dengan metode analisis deskriptif kualitatif. Hasil penelitian menunjukkan Yayasan pada beberapa tahun terakhir tidak memberikan subsidi secara langsung tiap bulannya untuk kepentingan Pesantren disebabkan karena beberapa alasan di atas, meskipun yayasan tetap memberikan bantuan secara insidentil kepada pesantren Adlaniyah.
\end{abstract}

Kata kunci: Pengelolaan Wakaf, Pemanfaatan Harta Wakaf, Wakaf Produktif 


\begin{abstract}
Management of waqf must be directed to the management of waqf effectively and efficiently. Waqf management is the process of making planning, organizing, leadership, and controlling various businesses from Nazhir, then using all of the organization's resources to achieve goals. According to data obtained by the Adlaniyah Islamic Boarding School Foundation has a wealth of land, the land came from the waqf of Nazri Adlani and was bought from residents. On that land, a class building and a dormitory have been partially planted with oil palm. The results of the oil palm plantations were initially used for school operations but in recent years the results of the oil palm plantations were taken by the foundation. While according to the provisions of waqf should be for the benefit of the people but in reality, it is used for personal gain. Departing from this, this writer conducted further research on the management of productive waqf at the Adlaniyah Islamic Boarding School Foundation Tampus Ujung Gading, Lembah Melintang District. In this study, the author uses the type of field research that is conducting field research by conducting direct interviews with administrators of the Adlaniyah Islamic Boarding School Foundation regarding the management of productive waqf at the Adlaniyah Islamic Boarding School Foundation Tampus Ujung Gading, Lembah Melintang District to find complete data related to this problem. In this study, the authors sought and collected data through interviews and documentation at the Adlaniyah Foundation Board and Islamic Boarding School Administrators. To obtain relevant data, the authors used data collection techniques, interviews, observations, and literature. After the data is collected, it will be analyzed by descriptive qualitative analysis methods. The results showed the Foundation in recent years did not provide direct subsidies every month for the benefit of the Islamic Boarding School due to some of the reasons above, although the foundation continued to assist incidentally to the Adlaniyah Islamic Boarding School.
\end{abstract}

Keywords: Management of Waqf, Utilization of Waqf Treasures, Productive Waqf 


\section{A. INTRODUCTION}

In waqf, language comes from Arabic, namely waqafa means "to hold". Some say from the word waqf means alhabs is a masdar word meaning to hold, stop, or be quiet. If the word is associated with property such as land, animals and others, it means a freezing of ownership for certain benefits. ${ }^{2}$ While in terms of endowment is holding assets both temporarily and for a long time to be used directly or indirectly, and the benefits are taken repeatedly (rewards) in the way of virtue, both general and special. ${ }^{3}$ In Pasal 1 Undang-Undang Nomor 41 Tahun 2004 concerning Waqf it is explained that waqf is a legal act of wakif (issuing person) to separate and surrender a portion of the possessed property to be used forever or for a specified period by its interests for worship and general welfare according to sharia. $^{4}$

According to Mundzir Qahaf, productive waqf is waqf whose principal goods are used for production activities, and the objectives of waqf give the results. $^{5}$ Furthermore, Jaih Mubarok

${ }^{1}$ Sayyid Sabiq, Fiqh as-Sunnah, (Beirut: Li at-Thaba'ah wa al-Nasyair, 1983), Jilid 3, 378. See too, Wahbah al-Zuhaily, Al-Fiqh al-Islami wa Adillatuhu, (Damsik: Dar al-Fikr, 2008), 151.

2 Andri Soemitra, Bank dan Lembaga Keuangan Syariah, (Jakarta: Kencana Prenada Media Group, 2009), 429.

3 Mundzir Qahaf, Manajemen Wakaf Produktif, (Penerjemah)Muhyiddin Mas Rida, (Jakarta: Khalifa, 2005), 52. According to Muhammad bin Ismail al-Kahlan, waqf in terms of holding property that may be taken advantage of with the permanent substance, and is used on the road that is allowed. See, Muhammad bin Ismail al-Kahlani, Subul as-Salam, (Mesir: Maktabah Dahlan Multazam Thobasyir, 852 H), 87.

4 Kompilasi Hukum Ekonomi Syariah (KHES), (Bandung: Fokus Media, 2010), 213

5 Mundzir Qahaf, Manajemen Wakaf Produktif, (Penerjemah)Muhyiddin Mas Rida..., 54. defines productive waqf is the management of waqf that can increase and add benefits to waqf objects that are managed naturally and professionally. ${ }^{6}$ According to Mundzir Qahaf we can differentiate the results or products of waqf property into two parts: 1) Waqf property that produces services in the form of goods for direct consumption by people who are entitled to waqf; 2) Waqf assets that are managed for investment purposes and deliver products or services that are sharia. ${ }^{7}$ The legal basis for the implementation of waqf, as mentioned in Surah Al-Imran verse 92:

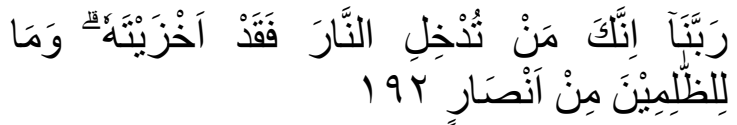

Meaning:

Our Lord, indeed whoever You admit to the Fire - You have disgraced him, and for the wrongdoers there are no helpers. (Q. S. 3: 92) ${ }^{8}$

In addition to the above verse the Prophet s.a.w. also mentions in a hadith narrated by Imam Ahmad:

If the child of Adam is dead, then all his deeds are cut except (one) of the three cases, namely: Sadaqah Jariyah, useful knowledge and pious children who pray for it. ${ }^{9}$

Charity fingeryah in the form of waqf will be considered valid by sharia if

6 Jaih Mubarok, Wakaf Produktif, (Jakarta: Khalifa, 2008), 15.

7 Mundzir Qahaf, Manajemen Wakaf Produktif, (Penerjemah)Muhyiddin Mas Rida..., 60-61.

8 Departemen Agama RI, Al-Quran dan Terjemahnya, (Bandung: Diponegoro, 2008), 62. See too, Q. S. al-Baqarah (2) ayat 267 and Q. S. alHajj (22) ayat 77.

9 Abdullah bin Abdurrahman al-Bassam, Syarah Bulughul Maram, (Jakarta: Pustaka Azzam, 2006), 119. 
it meets the following requirements: 1) Waqif; 2) Mauquf bih (assets represented); 3) Mauquf alaih (waqf target); 4) Nazhir (waqf manager); ${ }^{10}$ 5) Sighat lafaz; ${ }^{11}$ 6) Duration of waqf. $^{12}$ Land use is classified according to a letter from the Minister of Home Affairs CQ. Director-General of Agriculture No. 593/2483 / Agr. 22-61982 addressed to the Governor of KDH. Tk I up. Head of Provincial Agrarian Directorate throughout Indonesia, three groups, will be seen as follows: 1) For worship purposes; 2) For social purposes; 3) To support the Muhammadiyah Association. Management of waqf that is conducted leads to waqf activities effectively and efficiently. ${ }^{13}$ Waqf management is the process of making planning, organizing, leadership, and controlling various businesses from Nazhir, then using all of the organization's resources to achieve goals. ${ }^{14}$

According to Adlaniyah, Head of the Kantor Urusan Agama (KUA) of the Lembah Melintang District, the Islamic Boarding School Foundation has a wealth of land, the land came from the waqf of Nazri Adlani and was bought from

10 Nurul Huda dan Muhammad Haikal, Lembaga Keuangan Islam Tinjauan Teoritis dan Praktis, (Jakarta: Kencana Media Group, 2010), 313.

${ }^{11}$ Adijani al-Alabij, Perwakafan Tanah di Indonesia Dalam Teori dan Praktek, (Jakarta: PT Raja Grafindo Persada, 2004), 37. See too, Mardani, Ayat-Ayat dan Hadis Ekonomi Syariah, (Jakarta: Rajawali Pers, 2011), 13.

12 M. Nur Rianto al-Arif, Lembaga Keuangan Syariah Suatu Kajian Teoritis dan Praktis, (Bandung: CV Pustaka Setia, 2012), 408. See too, Beni Ahmad Saebani dan Syamsul Falah, Hukum Perdata Islam di Indonesia, (Bandung: CV Pustaka Setia, 2011), 265.

${ }^{13}$ Adijani al-Alabij, Perwakafan Tanah di Indonesia Dalam Teori dan Praktek..., 108.

14 Rozalinda, Manajemen Wakaf Produktif, (Jakarta: PT Raja Grafindo Persada, 2015), 74. residents. ${ }^{15}$ On that land, a class building and a dormitory have been partially planted with oil palm. The results of the oil palm plantations were initially used for school operations, but in recent years the results of the oil palm plantations were taken by the foundation on the pretext that school operational costs were sufficient from SPP. ${ }^{16}$ While according to the provisions of waqf should be for the benefit of the people but in reality, it is used for personal gain. Departing from this, this writer conducted further research on the management of productive waqf at the Islamic Boarding School Foundation, Adlaniyah Tampus Ujung Gading, Lembah Melintang District

\section{Research methods}

In this study, the author uses the type of field research that is conducting field research by conducting direct interviews with administrators of the Adlaniyah Islamic Boarding School Foundation regarding productive waqf management at the Adlaniyah Islamic Boarding School Foundation in Tampus Ujung Gading, Ujung Melintang District to find complete data relating to this problem. In this study, the authors sought and collected data through interviews and documentation at the Board of Trustees and the Board of Trustees of the Adlaniyah Islamic Boarding School. To obtain relevant data, the authors use data collection techniques: 1) Interviews; 2) Observation $^{17}$; 3) Documentation. After

15 Syahril, Head of KUA Lembah Melintang District, Interview, Lembah Melintang, 24 October 2018.

16 Supriadi Rasyid, Director TMI Adlaniyah, Interview, Ujung Gading, 27 October 2018.

17 Suharsimi Arikunto, Prosedur Suatu Pendekatan Praktik, (Jakarta : PT. Rineka Cipta, 2006), 155. 
the data is collected, it will be analyzed with a qualitative descriptive analysis method, which is to reveal what happened in the field at the time of this research, then the data is analyzed to produce specific laws.

\section{B. RESULTS AND DISCUSSION Management of the Adlaniyah Islamic Boarding School Foundation's Productive Waqf}

Management of productive waqf in the Adlaniyah Islamic Boarding School Foundation is inseparable from the relationship between direct waqf property and productive waqf property because of the interrelationship between the two. The Islamic Boarding School Foundation Waqf Adlaniyah has productive waqf which is aimed at direct waqf operations, namely the Islamic Boarding School Adlaniyah by the waqf. To achieve the objectives of waqf in terms of its management the foundation has various work programs in which there is a link between the assets of the endowment with the productive waqf. In the case of productive waqf management, there are four efforts so that waqf management activities run effectively and efficiently, namely:

\section{Planning}

The Adlaniyah Islamic Boarding School Foundation has a waqf land area of $3,800 \mathrm{~m}^{2}$, which is represented by Nazri Adlani who in his preparation aims at religious education or the establishment of Islamic Boarding School. On the land, there are direct waqf property and productive waqf property. Umar stated that:

The Adlaniyah Islamic Boarding School Foundation has a waqf land area of $3,800 \mathrm{~m}^{2}$ which is used for religious education. On this land currently stands a building in the form of dormitories, houses for teaching staff, mosques, own foundation houses, and others. There are even oil palms planted since the 1990s that were planted around the Pondok building. There are several buildings on the land, namely the Egyptian, Makkah, and Medina buildings as a place for female students' dormitory and the Santi Ketan building for teaching rooms. The multipurpose building as a place to eat students and as a venue for events, the Cordoba building is used as a religious teacher's room and language laboratory. The Libia building is used for radio studios, cooperatives, and canteens, the Indonesian building is used for students dormitories, clerics and rooms of clerics, the Aligarh building for administrative and class offices, the Syrian building is used for classrooms, the al-Kahf building for cleric rooms, the al Azhar as a class, a security guard room, then there is a turnover room, a house where the employee lives and cooks a kitchen. ${ }^{18}$

The Foundation has direct waqf property and productive waqf as explained above, so it can be concluded that the productive waqf property in waqf land in the form of oil palm plantations is planned to be aimed at managing Adlaniyah Islamic Boarding School.

\section{Organizing}

Regarding the management of Islamic Boarding School Foundation waqf Adlaniyah in the form of an organization, which has its own management structure.

18 Muhammad Umar Adlani, Deputy Chair 1 of the Adlaniyah Islamic Boarding School Foundation, Interview, Ujung Gading, 17 November 2018. 
In addition, the management of a foundation cannot be separated from its work program, there are several work program divisions, Mustaqiem states:

There are several fields in the Adlaniyah Islamic Boarding School Foundation programs, namely administration, organization, facilities and infrastructure, education and social welfare. Of all the fields there are also parts for each field, the administrative sector conducts financial administration and membership structuring and also infrastructure and infrastructure information. The part of the organization is about the management of foundations and the dissemination of AD/ ART. The facilities and infrastructure section made the foundation's office and its equipment and established the Islamic Boarding School as it has been established since 1978. The education sector increased work relations between the foundation's management and educational institutions, both formal and non-formal. Increasing the welfare of education personnel. In the economic and financial sector, the development of other efforts to increase foundation funds, which currently exists, is oil palm plantations that have been planted since the 1990s, which are on the sidelines of the Islamic Boarding School building. The field of social welfare, providing the welfare of the foundation's administrators, Giving scholarships to underprivileged students who excel. $^{19}$

From the above interview it can be understood that the foundation provides assistance in the form of free schools for high-achieving students who are economically disadvantaged to be able to attend Adlaniyah Islamic boarding school.

\section{Actuating}

The foundation which acts as the manager of waqf for the Adlaniyah Islamic Boarding School Foundation is tasked with religious education. Productive Waqf which is on waqf land in the form of oil palm planted between the buildings is planned to assist in managing the boarding school by the foundation. So it is the foundation that has the right to manage all the properties of waqf that are on the land and manage the Islamic boarding school how to keep the Islamic Boarding School going well and productive waqf remain and develop.

In terms of leadership, the foundation conducts training at least once every six months given by the General Chairperson of the Islamic Boarding School Foundation, Adlaniyah who also provides motivation to be able to manage the foundation and under its auspices. Because to become a waqf manager it must meet certain criteria. If referring to the law, the endowment manager, namely the foundation, is not according to the law because in this case the management is not chosen based on the ability or experience of endowment management, but based on family lines.

The oil palm on waqf land was planted by the foundation in 1991 for the purpose of supporting the management of Adlaniyah Islamic Boarding School

19 Mustaqiem, Head Adlaniyah Islamic Boarding School, Interview, Ujung Gading, 26 November 2018. 
education, but in reality the results of the productive waqf were used for the foundation's personal interests. Based on the results of an interview with Salamat as manager of the financial department foundation stated that:

The results of the foundation's oil palm plantations every time they are issued are only for employee salaries: harvest, care, supervision and financial employees and the rest are directly transferred to the head of the central foundation, Hadiyanti. The results are then stored and used for the foundation's personal benefit. However, in its rotation once every four months the foundation spends money on garden maintenance in the amount of Rp. 3,500,000, and for other purposes. ${ }^{20}$

Based on the above explanation it is clear that the results of the Adlaniyah Islamic Boarding School Foundation's productive waqf are used to support the development and management of education but in reality almost all of the results of these waqf are used by the foundation for personal gain. The Adlaniyah Islamic Boarding School Foundation oil palm plantation is harvested every three weeks or approximately 20 days by employees. The yield of oil palm reaches 2.5 tons in each harvest. The price of oil palm at that time was increasing, the income obtained by the foundation also increased. At that time the price of oil was estimated at Rp. $1,450.00 / \mathrm{Kg}, 2.5$ tons x Rp. 1,450 = Rp. $3,625,000$. Then it can be estimated that the income earned by the foundation from

\footnotetext{
20 Salamat Lubis, Teacher Adlaniyah Islamic Boarding School, Interview, Ujung Gading, 17 November 2018.
}

oil palm plantations is Rp. $3,625,000 / 3$ Weeks.

Within three weeks the oil palm was harvested by the employees, the money from the harvest was given to the finance department, Salamat Lubis. The amount of Rp. 3,625,000 withheld for payment of maintenance and harvest employee salaries of Rp. 500,000 and Rp. Another 500,000 to pay the salaries of the oil palm plantation supervisors and the finance department. So each time the money is immediately deducted $\mathrm{Rp}$. $1,000,000$ for payment of employee salaries. Palm oil that has been deducted for employee salary payments is then sent to Hadiyanti who is in Jakarta (Chairperson of the Central Foundation). For the maintenance costs of oil palm plantations, the money must be spent on fertilizers once every 4 months or $5 \mathrm{x}$ harvest Rp. 3,500,000. Within 4 months or $5 \mathrm{x}$ the yield is estimated at Rp. 3,625,000. $\mathrm{x}(5 \mathrm{x}$ Harvest $)=$ Rp. 18,125,000. The overall result is Rp. 18,125,000 3,500,000 (maintenance costs) - Rp. $5,000,000$ (employee salary) $=\mathrm{Rp}$. 9,625,000.

In previous years the foundation still provides subsidies every month to the Adlaniyah Islamic Boarding School for education support, but in recent years the foundation has not provided subsidies every month. The author's interview with the chairman of the Islamic Boarding School Foundation branch Adlaniyah said that:

The management of the foundation does not provide subsidies every month to the Islamic Boarding School or for the benefit of students in the last few years because there are already a lot of Islamic Boarding School students in Adlaniyah. Therefore, Adlaniyah Islamic Boarding 
School has been able to stand alone without any subsidies from the Islamic Boarding School. In the past, the Adlaniyah Islamic Boarding School was still subsidized every month because there were still very few students. ${ }^{21}$ Departing from the explanation above, it can be understood that in the last few years the foundation has always provided subsidies every month for Islamic boarding schools, but in recent years the foundation has not used the results of oil palm plantations for the benefit of the Adlaniyah Islamic Boarding School but used for the benefit of the foundation itself. Islamic Boarding School Adlaniyah, his journey in recent years only relies on tuition fees from students for teacher salaries and other needs. Although at certain times, the foundation also assists.

Nazhir must manage and develop waqf property by waqf objectives. But based on the interview above the Islamic Boarding School Adlaniyah used to be endowment property that has been developed by the function and purpose of endowment designation, but at this time it has not been achieved as the function and purpose of waqf even though at certain times the foundation assists at Islamic Boarding Schools. Thus, without the results of these oil palm plantations, the Islamic Boarding School continues to run well, and its students also increase from year to year. The increase in students is due to the achievements of the students so that the Islamic Boarding School Adlaniyah is increasingly known and sought after. The community is not afraid to send their children to the Islamic

21 Muhammad Umar Adlani, Deputy Chair 1 of the Adlaniyah Islamic Boarding School Foundation, Interview, Ujung Gading, 25 November 2018.
Boarding School even though the cost is more expensive than other schools in West Pasaman Regency. It is the number of students who enter each year and the higher fees from these schools that keep the Adlaniyah Islamic Boarding School continuing to run well even though they do not get subsidies every month from the Foundation.

Based on Undang-Undang Nomor 41 Tahun 2004, it is explained that Nazir, as the manager of the waqf, is only entitled to get $10 \%$ of the results of waqf management. But based on observations made by the author, the author sees almost all of the harvest was taken over by the foundation, even though the foundation still assists at the Islamic Boarding School not like it used to. Although Islamic Boarding School can run well without the results of the oil palm plantations but returned to the purpose of the allocation of waqf to support the management of Islamic Boarding School education. So the management of productive Islamic Boarding School Adlaniyah waqf is not yet suitable in terms of the purpose of the allotment and compensation that must be obtained by the foundation as the manager.

\section{Controlling}

Supervision is a process to ensure that the activities carried out as planned. Waqf management, namely the foundation, conducts monitoring or evaluation of what has been carried out once a year. Besides, the administration conducted an evaluation, but based on its management, the productive waqf of the foundation were used more for the foundation's needs and are still ongoing.

\section{Utilization of Adlaniyah Islamic Boarding School Foundation Productive Waqf Results}


Waqf, according to the Law and Jurisprudence, aims to improve the progress of the welfare of the people. As productive waqf in Islamic Boarding School Adlaniyah that productive waqf is intended to support religious education. Adlaniyah's Islamic Boarding School Foundation's productive Waqf is in the form of oil palm plantations which are planted on the sidelines of the Islamic boarding school building. Palm yields in three weeks are estimated to be around 2.5 tons (not always fixed) or around $\mathrm{Rp}$. $3,625,000$. Salamat said that the results of the productive waqf of the Adlaniyah Islamic Boarding School Foundation were used as a private foundation for the foundation, the incidental needs of the foundation, the ancillary needs of the Islamic Boarding School. ${ }^{22}$ From the above interview, it can be understood that the results of productive waqf are used for:

First, the foundation's personal needs. Furthermore, Shella said that the foundation's demand for electricity in the form of foundation houses in Ujung Gading and Padang, which each month is more than Rp. 500,000 and the private telephone of the foundation in Ujung Gading and Padang each month reach approximately 850,000 salaries for foundation housemaid one Rp 800,000 per person in Ujung Gading. ${ }^{23}$

Second, the incidental needs of the foundation. These needs are like the maintenance and repair of damage to foundation houses located in Ujung Gading and Padang. It is not always damaged in every month but this need is intended as an act of anticipation. Next to

22 Salamat Lubis, Teacher Adlaniyah Islamic Boarding School, Interview, Ujung Gading, 17 November 2018.

23 Shella Donna Bayu Nanda, Teacher Adlaniyah Islamic Boarding School, Interview, Ujung Gading, 26 November 2018. the security of the foundation's house, to anticipate theft and increase guards such as security guards. ${ }^{24}$ From the above interview, it can be understood that the incidental needs of the foundation include the maintenance and repair of damage to the foundation's house in Ujung ivory and in Padang, although not always damaged in each month sometimes some want to be replaced such as water pipes, building roofs, and so forth. Then the second is for the security of the foundation's house, to guard against theft, the security around the foundation is increased.

Third, the incidental needs of Islamic boarding schools. Besides being used for the benefit of foundations, the results of productive waqf are used for ancillary interests of the Islamic Boarding School. Salamat stated the incidental needs of the Islamic Boarding School Adlaniyah, namely grand performances or art performances held once a year which is usually funded by contributions from students and students' parents. The foundation helps if the money collected by the Islamic Boarding School is still lacking. In addition to repairing the bridge, Adlaniyah has one bridge that is sometimes damaged because it is often passed by oil palm transport trucks, so to improve the foundation using productive endowment money. Drainage improvement, water channels are right for female students, students, and others sometimes suffer damage, so need repair from a handyman. Salamat further stated that:

The reason the foundation does not provide subsidies every month is that the Islamic Boarding School have been able to stand on their

24 Salamat Lubis, Teacher Adlaniyah Islamic Boarding School, Interview, Ujung Gading, 17 November 2018. 
own without economic assistance from the foundation. The Students already has a lot of funds so that the operational funds used from SPP are sufficient. The condition of oil palm plantations is also old because oil palm has been planted since the 1990s. So the current income is only around 2.5 tons per month. The foundation still assists at Islamic Boarding School, but only at certain moments that are incidental. Regarding social welfare programs such as assistance for needy students who excel, there still exists but not from the results of productive waqf but other student tuition fees managed by the Islamic Boarding School. ${ }^{25}$

Departing from the explanation above, it should be seen again that the purpose of waqf is to be utilized within limits allowed by Islamic law. According to Law Number 41 of 2004, Article 22, it is explained that the purpose of waqf is:

\section{Means of worship and worship activities}

The Adlaniyah Islamic Boarding School Foundation as a waqf manager in terms of religious facilities and worship activities according to this Law has achieved this goal. This can be seen from the waqf land established by the Islamic Boarding School as well as the mosque which aims to conduct worship for students and parties visiting the Islamic boarding school, namely the students' families and guests of the foundation and the teachers and employees of the Islamic Boarding School.

\section{Education and health facilities and activities}

25 Salamat Lubis, Teacher Adlaniyah Islamic Boarding School, Interview, Ujung Gading, 26 November 2018.
If seen from the foundation's educational facilities, the objectives have been achieved. Because it is used to establish Islamic boarding schools to date more and more students, and achievements in education are increasing. While health facilities at this foundation do not yet exist.

\section{Assistance to the poor, neglected and orphaned children}

Regarding assistance to the poor, abandoned and orphaned children, the foundation provides scholarships for students. In accordance with the foundation's work program that is improving social welfare. In this case the foundation has achieved the endowment goals in waqf laws in the field of social welfare. The foundation provides scholarships to the poor and orphans on condition they have excellent achievements or grades. While initially, the assistance provided did not come from the results of productive waqf but SPP students managed by the Islamic Boarding School.

\section{Progress and improvement of the economic community}

In this case, the Adlaniyah Islamic Boarding School Foundation has not yet reached the stage of development and development of the financial community, because seen from the use of all waqf has only circulated for the foundation itself and the Islamic boarding school. Although there is a section for Islamic boarding schools, it cannot be said that the economy, in this case, has improved. But when viewed from the use of the results of productive waqf, the foundation is more dominating for the benefit of the foundation itself than for the interests of the Islamic Boarding School, although in this case the Islamic Boarding School has been able to operate independently without any subsidies from the foundation. 
The Adlaniyah Islamic Boarding School Foundation as the manager of the waqf has achieved the endowment goals stipulated in the Act although in terms of managing productive waqf outcomes it is more dominating the waqf results for the foundation itself. Besides, if you look back at the foundation's work program has not been fully achieved, such as the promise of the foundation will provide benefits to Islamic boarding school educators. This is because the results of productive waqf in the form of oil palm plantations are insufficient to be addressed in the provision of benefits to Islamic boarding school educators.

Nazhir waqf, namely the foundation as the manager of the waqf is described in Pasal Undang-Undang Nomor 41 Tahun 2004 which has the following tasks:

\section{Administering waqf property}

In this case, the foundation as the manager has carried out its duties, namely, the administration of waqf property in the work program of the Adlaniyah Islamic Boarding School Foundation is an inventory of facilities and infrastructure of the foundation which includes both movable and immovable waqf assets which are on the waqf land.

\section{Manage and develop waqf property} following its purpose, function and designation

The task of the foundation as a manager has also been to manage and build waqf property in accordance with its objectives, functions and designation, although it has not yet been fully achieved. As was done by the foundation by planting oil on the sidelines of the Islamic boarding school building so that in this case the waqf property develops and helps the Islamic boarding school operate when the Islamic Boarding School students are still small. Oil palm plantations as productive waqf in the plan are for Islamic boarding school operations, but in recent years the results of productive waqf are intended for the private interests of the foundation even though the foundation assists at the Islamic Boarding School, but that is only incidental. So the allocation of waqf property which is supposed to help the Islamic Boarding School operations, in this case, has not yet been fully achieved.

\section{Supervise and protect waqf property}

The foundation as the manager of waqf property can be said to have carried out its duties in terms of protecting and supervising waqf property. It can be seen that the features of waqf which are under the auspices of the Adlaniyah Islamic Boarding School Foundation are not reduced at all, there is always an increase every year, for example, the construction of buildings for the benefit of the Islamic Boarding School even though the building is not derived from the results obtained from waqf managed by the foundation.

\section{Reporting the implementation of tasks regularly to the Minister and the Indonesian Waqf Board}

In the case of carrying out tasks regularly to the Minister and the Indonesian Waqf Board, the foundation as a waqf manager has not yet carried them out. As Umar stated, the foundation never reported anything regarding waqf that we managed with the Kantor Urusan Agama (KUA), the Minister and BWI. ${ }^{26}$

From the interview above, it can be understood that the foundation did not report everything related to the waqf managed either to the KUA, the Minister and BWI. The Foundation has almost

26 Muhammad Umar Adlani, Deputy Chair 1 of the Adlaniyah Islamic Boarding School Foundation, Interview, Ujung Gading, 29 November 2018. 
carried out its duties as a waqf manager, but in terms of the distribution and management of the results of productive waqf many discrepancies were made by the foundation. For example, the foundation manages waqf property but does not distribute it as it should. In terms of achieving the goals of waqf according to waqf law, however, waqf such as Islamic Boarding Schools do not originate from productive waqf managed by foundations, but from SPP students.

\section{CONCLUSION}

Management of productive waqf in the Adlaniyah Islamic Boarding School Foundation Tampus Ujung Gading, Lembah Melintang District, West Pasaman Regency is not by the purpose and benefits of the endowment designation. Productive Waqf which should be earmarked for the development and management of Adlaniyah Islamic boarding school but in reality has not been achieved even though the foundation assists incidentally. In terms of productive waqf management, the results obtained from the Foundation gardens are almost entirely used for the benefit of the Adlaniyah Islamic Boarding School Foundation itself. But in terms of Nazir responsibilities and objectives of waqf are by statutory regulations. The foundation manager who according to the laws and regulations only gets $10 \%$ of the results of the management of the waqf but in fact, violates the applicable provisions. Even though the Islamic Boarding School Adlaniyah can run well without a monthly subsidy from the foundation, but as the manager should only take part by applicable laws and regulations.

Utilization of productive waqf in the Adlaniyah Islamic Boarding School Foundation Tampus Ujung Gading Lembah Melintang District, West
Pasaman Regency according to Islamic law. The results of the productive waqf of the Adlaniyah Islamic Boarding School Foundation Tampus Ujung Gading, Lembah Melintang District, West Pasaman Regency are used as follows: 1) The foundation's personal needs, 2) The foundation's incidental needs, 3) The ancillary requirements of the Islamic Boarding School.

Therefore it can be concluded that the Foundation in recent years has not provided direct subsidies every month for the benefit of the Islamic Boarding School due to some of the reasons above, although the foundation continues to assist incidentally to the Adlaniyah Islamic Boarding School. However, if seen from the use of productive waqf results above the more dominant is for the personal needs of the Foundation itself, although the foundation argues that the Islamic Boarding School Adlaniyah has been able to stand alone without subsidies from the Foundation. However, if you see the purpose of the designation of productive waqf to support the education of Islamic boarding schools, it can be concluded that the use of fruitful waqf results is not by Islamic law, which is for the welfare of the people or by the purpose of endowment and is not by applicable laws and regulations. Although the purpose of waqf and the duties of Nazhir are almost entirely fulfilled, in terms of the use of the results of waqf are not by the objectives and allotment of waqf.

\section{REFERENCES}

al-Alabij, Adijani, 2004, Perwakafan Tanah di Indonesia Dalam Teori dan Praktek, Jakarta: PT Raja Grafindo Persada. 
al-Arif, M. Nur Rianto, 2012, Lembaga Keuangan Syariah Suatu Kajian Teoritis dan Praktis, Bandung: CV Pustaka Setia.

al-Bassam, Abdullah bin Abdurrahman, 2006, Syarah Bulughul Maram, Jakarta: Pustaka Azzam.

al-Kahlani, Muhammad bin Ismail, $852 \mathrm{H}$, Subul as-Salam, Mesir: Maktabah Dahlan Multazam Thobasyir.

al-Zuhaily, Wahbah, 2008, Al-Fiqh alIslami wa Adillatuhu, Damsik: Dar al-Fikr.

Arikunto, Suharsimi, 2006 Prosedur Suatu Pendekatan Praktik, (Jakarta : PT. Rineka Cipta.

Departemen Agama RI, 2008, Al-Quran dan Terjemahnya, Bandung: Diponegoro.

Huda, Nurul dan Muhammad Haikal, 2010, Lembaga Keuangan Islam Tinjauan Teoritis dan Praktis, Jakarta: Kencana Media Group.

Kompilasi Hukum Ekonomi Syariah (KHES), 2010, Bandung: Fokus Media.

Mardani, 2011, Ayat-Ayat dan Hadis Ekonomi Syariah, Jakarta: Rajawali Pers.

Mubarok, Jaih, 2008, Wakaf Produktif, Jakarta: Khalifa.

Qahaf, Mundzir, 2005, Manajemen Wakaf Produktif, (Penerjemah) Muhyiddin Mas Rida, Jakarta: Khalifa.
Rozalinda, 2015, Manajemen Wakaf Produktif, Jakarta: PT Raja Grafindo Persada.

Sabiq, Sayyid, 1983, Fiqh as-Sunnah, Beirut: Li at-Thaba'ah wa alNasyair, Jilid 3.

Saebani, Beni Ahmad dan Syamsul Falah, 2011, Hukum Perdata Islam di Indonesia, Bandung: CV Pustaka Setia.

Soemitra, Andri, 2009, Bank dan Lembaga Keuangan Syariah, Jakarta: Kencana Prenada Media Group. 